\title{
The foreign exchange exposure of UK non-financial firms: A comparison of market- based methodologies
}

\author{
By \\ Sam Agyei-Ampomah ${ }^{\mathrm{a}}$, Khelifa Mazouz ${ }^{\mathrm{b}}$ and Shuxing Yin $^{\mathrm{c}}$ \\ ${ }^{a}$ Surrey Business School \\ ${ }^{b}$ Bradford University School of Management \\ ${ }^{c}$ Sheffield Management School
}

\begin{abstract}
We use a sample of 269 UK non-financial firms to study the sensitivity of foreign exchange exposure, and its determinants, to the different estimation methods. The standard Jorion's model suggests that $14.93 \%(30.50 \%)$ of the firms in our sample are exposed directly or indirectly to the fluctuations in the TWC (the US\$, the Euro or the JP¥). However, the exposure increases substantially to $85.13 \%$ (96.65\%) when time varying exposure regressions with orthogonalized market returns are used. We also show that the determinants of currency exposure are model-dependent. While the cross-sectional results suggest very little or no relationship between firm-specific factors and currency exposure, the explanatory power of these factors increase when data is pooled across firms and time.
\end{abstract}

JEL Classifications: F31; F23

Keywords: Foreign exchange exposure; Currency risk; Panel estimation 


\section{Introduction}

Several studies predict that all firms should be subject to foreign exchange exposure as their cash flows are affected, directly or indirectly, by exchange rate movements (Shapiro, 1975; Heckman, 1985; Levi, 1994; Marston, 2001). In the light of this, it is puzzling why most empirical studies show that foreign exchange fluctuations have little or no impact on stock returns (Jorion, 1990; Bartov and Bodnar, 1994; El-Masry et al. 2007; Hutson and Stevenson, 2010).

This study uses a sample of 269 UK non-financial firms to investigate whether the weak empirical association between exchange rate changes and stock returns can be attributed to bad model problems. Our analysis makes three important methodological contributions to the literature on the foreign exchange exposure of individual firms. First, we relax Jorion's (1990) assumption that foreign exchange exposure is constant over time. Several studies (Smith and Stulz, 1985; Allayannis and Weston, 2001; Dunne et al., 2004) show that a firm's exposure to exchange rate movements is related to firm-specific factors, such as size, liquidity, hedging activities and growth opportunities, which are expected to vary over time. We use GARCH-based two-factor asset pricing model with time varying coefficients (GARCH-TVC hereafter) to model the time varying nature of firms' exposure to currency movements. ${ }^{1}$ Second, Priestley and Ødegaard (2007) argue that the exposure coefficient obtained from Jorion's model does not capture the stock's total exposure to the foreign exchange movements. Instead, it only measures the stock's exposure over and above that of the market portfolio. Priestley and Ødegaard (2007) suggest that orthogonalized, rather than actual, market returns should be used to estimate the exchange rate exposure. We improve on Priestley and $\varnothing$ degaard's (2007) methodology by allowing the coefficients and the residuals of the orthogonalized regressions to vary over time. Finally, previous studies use cross-sectional analysis to examine the determinants of the foreign exchange exposure. Although some of these determinants, such as industry, vary only across firms, others vary across firms and time ${ }^{2}$. We contend that cross-sectional analysis is likely to generate biased estimates, as it ignores the temporal dimension of both dependent and explanatory variables. To overcome these potential estimation biases, a panel approach is used to examine the determinants of foreign exchange exposure.

Our analysis yields two important results. First, we show that the foreign exchange exposure of individual firms is highly sensitive to the estimation methods. Jorion's model

\footnotetext{
${ }^{1}$ A similar model is adopted by Patro et al (2002) to study the foreign exchange exposure of stock indexes.

${ }^{2}$ See, for example, Baltagi (2005) for more details on the advantages of panel data analysis.
} 
implies that $14.93 \%$ (30.50\%) are exposed, directly or indirectly, to TWC (US\$, Euro or JP¥). However, the GARCH-TVC indicates that $75.84 \%(78.07 \%)$ of the sample firms exhibit at least one yearly significant exposure to the TWC (US\$, Euro or JP¥) over the study period. These percentages increase further to $85.13 \%$ (96.65\%) when orthogonalized GARCH-TVC model is adopted. This evidence indicates that failure to account for the time varying nature of currency risk exposure helps to explain the weak empirical relationship between stock returns and currency fluctuations reported by most studies in the literature. Second, we show that the determinants of currency exposure are also model-dependent. While cross-sectional analysis reveals little or no relationship between currency exposure and firm-specific factors, such as size, growth opportunities, liquidity and leverage, the explanatory power of some of these factors improve substantially under the panel data approach. Specifically, the panel results indicate that small firms and firms with low growth opportunities tend to be more exposed to exchange rate movements.

The remainder of the paper is structured as follows. Section 2 provides a brief review of the literature on the foreign exchange exposure and its determinants. Section 3 presents our methodology. Section 4 describes the sample and provides descriptive statistics. Section 5 reports empirical findings on foreign exchange exposure and its determinants. Section 6 concludes.

\section{Literature review}

\subsection{Currency exposure}

Economic theory suggests that firms are subject to foreign exchange exposure as their cash flows are driven, directly or indirectly, by changes in exchange rates. The direct exposure involves transaction exposure of expected future foreign currency cash flows (i.e. foreign currency receivables and payables). Indirect exposure arises from the impact of foreign exchange movements on the competitiveness of the firm. Consistent with these arguments, analytical research (see e.g. Shapiro, 1975; Heckman, 1985; Levi, 1994; Marston, 2001) predicts that exchange rate fluctuations are a major source of macroeconomic uncertainty that influence the returns and cash flows of corporations.

Given the theoretical expectation of a link between firm performance and exchange rates, one would expect empirical studies to establish this relationship. Yet, while early empirical studies (Jorion, 1990; Bartov and Bodnar, 1994; Amihud, 1994) almost suggest that foreign exchange movements do not affect stock prices, recent empirical research has produced mixed results. Dominguez and Tesar (2006) find that many publicly listed non-US 
firms from eight developed and emerging countries experience significant currency exposure. El-Masry et al. (2007) examine the foreign exchange exposure of 394 UK firms over the period 1981-2001. They show that only $15 \%$ of their sample firms are significantly exposed to the fluctuations in the TWC. In a multi-country study, Hutson and Stevenson (2010) find that only $8 \%$ of their 312 UK firms are exposed to currency index movements during the period 1984-2003.

Several firm-level studies attribute the weak empirical findings to exposure measurement biases. Fraser and Pantzaliz (2004), for example, show that the exposure of US multinationals to exchange rate changes depends on the foreign exchange index used in the exposure regression. Specifically, they show that $5.5 \%, 8.7 \%$ and $12.6 \%$ of their 310 sample firms exhibit significant exposure to MAJCUR index, firm-specific exchange rate index and FRB's BOARD currency index, respectively. Rees and Unni (2005) examine the exchange rate exposure of large firms in the UK, France and Germany. They find that European firms exhibit more exposure to bilateral exchange rates than currency indices. Chow et al. (1997) show the exchange rate exposure of US multinationals increases with the length of return horizon. Muller and Verschoor (2006) find that US multinationals react asymmetrically to currency movements. They also show that asymmetries are more pronounced towards large versus small currency changes than over appreciation and depreciation cycle. Using a sample of 935 US companies with real operations in foreign countries, they find that the percentage of firms with significant currency risk exposure increases from $7.27 \%$ to $29 \%$ after accounting for the asymmetric nature of the exposure. Tai (2008) also finds evidence of asymmetric currency exposure and asymmetry in the pricing of currency risk.

Several other methodological issues have been identified by industry- and index-level studies. Patro et al. (2002) examine the exchange rate exposure of index equity returns of 16 OECD countries. Using a GARCH specification, they find significant time-varying foreign exchange risk exposure. Priestley and $\varnothing$ degaard (2007) argue that since market portfolios are also exposed to currency fluctuations, including market returns in the exposure regression may cause spurious correlation between industry returns and exchange rate fluctuations. They show that the percentage of US industries exposed to movements of either JP¥ or Euros increases from $10.34 \%$ to $27.58 \%$ when orthogonalized, rather than actual, market returns and exchange rates are used in the linear exposure regressions. 
This study contributes to the literature on foreign exchange risk measurements by examining the individual and the combined effects of time-varying risk adjustments and market return orthogonalization on the foreign exchange exposure of individual firms.

\subsection{The determinants of currency exposure}

The extant literature documents that foreign exchange exposure depends on a number of country, industry and firm characteristics. Patro et al. (2002) examines the extent to which equity index returns exposure can be explain by a country's macroeconomic variables. They find that imports, exports, credit ratings and tax revenues significantly affect currency risk. De Jong et al. (2006) show that 50 percent of the Dutch firms are significantly exposed to exchange rate fluctuations. They argue that firms in open economies, such as the Netherlands, are likely to experience significant foreign exchange exposure. Hutson and Stevenson (2010) report a significantly positive (negative) association between country openness (creditor protection) and a firm's exposure to the exchange rate movements.

Many studies show that foreign exchange exposure varies significantly across industries. Bodnar and Gentry (1993) examines the foreign exchange exposure of the US, Canadian and Japanese industries. They show that the level of engagement in foreign transactions is an important determinant of industry sectors exposure. Similar results are reported by Williamson (2001) in the context of US and Japanese Automotive industry. Bodnar et al. (2002) argue that a firm's exposure depends on its ability to pass on the increased costs or prices resulting from exchange rate fluctuations to their customers. This, in turn, depends on industry competitiveness, which determines the price elasticity of demand, and the degree of substitutability of the goods. Marston (2001) shows that industry competitiveness has significant effect on firm-level exposure. However, Dominguez and Tesar (2001) find that trade measured at the industry level has little impact on the exchange rate exposure of individual firms. Their findings, they argue, suggests that firms in sectors with great quantity of foreign transactions are more likely to hedge.

In addition to the macroeconomic variables and industry competitive structure, firm characteristics, such as foreign operations, hedging activities, size, leverage, liquidity and growth opportunities, are also shown to affect foreign exchange risk exposure. Jorion (1990) find that US firms with high levels of foreign sales exhibit more positive exchange rate exposure. Booth and Rotenberg (1990) show that foreign sales, foreign assets and foreign debt are amongst the determinants of the sensitivity of Canadian stock returns to the US dollar movements. However, Aggarwal and Harper (2010) show that the foreign exchange exposure faced by domestic companies is not significantly different from that observed in the 
sample of multinational corporations. Nydhal (1999), Allayannis and Ofek (2001) and Nguyen and Faff (2003), among others, establish that the use of derivatives reduces exchange rate exposure. Bodnar and Wong (2003) show that small firms are more exposed to foreign exchange movements than large firms. This evidence is consistent with the finding that large firms are more likely to hedge their foreign exchange risk exposure (see e.g. Allayannis and Ofek, 2001; Hagelin and Pramborg, 2006; Bartram et al., 2010). Nance et al. (1993) show that hedging is particularly popular amongst firms with considerable growth opportunities, high probability of financial distress and low level of liquid assets.

Existing studies on the determinants of firms' exposure to exchange rate movements tend to use cross-sectional analysis, which ignores the temporal dimension of both dependent and explanatory variables. This study uses a panel data approach, which pools the data across firms and time, in order to improve estimation efficiency.

\section{Methodology and results}

\subsection{Exposure measurements}

The most widely used approach to detect the foreign exchange exposure is that of Jorion (1990), which is specified as follows

$R_{i t}=\beta_{i 0}+\beta_{i m} R_{m t}+\beta_{i s} s_{t}+\varepsilon_{i t}$

where $R_{i t}$ and $R_{m t}$ are the returns on a stock $i$ and a market portfolio $m$, respectively; $s_{t}$ represents the percentage change in the value of a single currency or basket of currencies; $\beta_{i 0}$ is a constant that varies across firms; $\beta_{i m}$ estimates stock $i$ 's market-wide exposure; $\beta_{i s}$ is the estimate of the FX exposure; $\varepsilon_{i t}$ is the residual error with a zero mean and a constant variance. $^{3}$

Since $R_{m, t}$ is simply the aggregation of the individual stocks, the market may also be exposed to the foreign exchange risk. Thus, the coefficients $\beta_{i s}$ in Eq.(1) do not measure the total exposure of stock $i$ to the exchange rate $s$, but rather the exposure over and above that of the market portfolio. To address this issue, we first estimate the orthogonalized market return from the following regression

\footnotetext{
${ }^{3}$ In line with the existing literature (e.g. Priestley and Ødegaard, 2007; Bartram and Karolyi, 2006), we study firm exposure to individual currencies by including changes in US\$, Euro and JP¥ in the same regression. Equation (1) therefore has two variations; one with $\beta_{i s} s_{t}=\beta_{i, T} T W C$, when the trade-weighted currency index is used and another with $\beta_{i s} s_{t}=\beta_{i, \$} U S \$+\beta_{i, €}$ Euro $+\beta_{i, ¥} \mathrm{JP} ¥$.
} 
$R_{m t}=\vartheta_{m} s_{t}+\tau_{m t}$

where $\tau_{m t}$ is defined as the orthogonalized market return, which captures the part of the market return that is not correlated with the exchange rate fluctuations. We then modify equation Eq.(1) as follows

$R_{i t}=\theta_{i 0}+\theta_{i m} \tau_{m t}+\theta_{i s} s_{t}+\varepsilon_{i t}$

In this case, the parameter $\theta_{i s}$ can be interpreted as the total exposure of stock $i$ to the exchange rate fluctuations.

The above equations assume that the currency risk associated with the market portfolio and individual firms is constant over time. However, Patro et al. (2002) find that stock index exposure to currency risk varies systematically with macroeconomic variables. We also argue that contemporaneous changes in firm-specific factors, such as size, financial stability and engagement in risk management activities can lead to time varying exposure of individual stocks to exchange rate movements. To account for the time varying risk and return characteristics, we modify the Eqs.(1), (2) and (3) as follows

$$
\begin{aligned}
& R_{i t}=\sum_{n=1}^{20} \alpha_{i, n} D_{n}+\sum_{n=1}^{20} \beta_{i m, n} D_{n} R_{m, t}+\sum_{n=1}^{20} \beta_{i s, n} D_{n} s_{t}+\mu_{i t} \\
& R_{m . t}=\sum_{n=1}^{20} a_{s, n} D_{n} s_{t}+\omega_{m, t} \\
& R_{i, t}=\sum_{n=1}^{20} \rho_{i, n} D_{n}+\sum_{n=1}^{20} \rho_{i m, n} D_{n} \omega_{m t}+\sum_{n=1}^{20} \rho_{i s, n} D_{n} s_{t}+\epsilon_{i t}
\end{aligned}
$$

where $D_{n}$ is a dummy variable with a value of 1 if $\mathrm{t} \in$ year $n$, where $n=1,2, \ldots, 20$, and zero otherwise. All the parameters in Eqs.(4), (5) and (6) are allowed to change from year to year and the residual terms, $\mu_{i t}, \omega_{m t}$ and $\epsilon_{i t}$, are assumed to follow a $\operatorname{GARCH}(1,1)$ process ${ }^{4,5}$. The parameters $\beta_{i s, n}$ in Eq.(4), $a_{s, n}$ in Eq.(5) and $\rho_{i s, n}$ in Eq.(6) capture the yearly exposure of a stock $i$ over and above that of the market portfolio, the yearly exposure of the market portfolio to foreign exchange movements and the total exposure of a stock $i$ to exchange rate

\footnotetext{
${ }^{4}$ The results of the LM test, which are available upon request, indicate presence of the ARCH effects in the residual errors of all sample stocks. These findings provide a strong support for the use of GARCH specification.

${ }^{5}$ Bollerslev et al. (1992) document that $\operatorname{GARCH}(1,1)$ process is sufficient to capture the volatility clustering in most of the financial data. Our data also suggests that most of the high-order GARCH parameters are not statistically significant.
} 
fluctuations, respectively. We use the Wald's test to gauge whether the exchange rate coefficients of a given stock are jointly equal to zero for all 20 years in the sample.

\subsection{The determinants of currency risk exposure}

Existing studies typically use cross-sectional regressions of the following form to examine the determinants of foreign exchange exposure

$\psi_{i}=\varphi_{0}+\sum_{k=1}^{K} \varphi_{k} x_{i, k}+\pi$

where $\psi_{i}$ refers to the exposure of firm $i$ to the exchange rate movements; $x_{i, k}$ is firm $i$ 's $k$ th explanatory variable; and $\pi$ is a random error term. We explore this issue under the alternative measures of exposure.

Our choice of explanatory variables is guided by the findings of the previous studies. Allayannis and Ofek (2001) and Hagelin and Pramborg (2006) document that large firms are more likely to hedge exchange rate fluctuations, as large firms benefit from economies of scale when hedging. Agarwal and Ramaswami (1992) suggest that large firms are likely to engage in international operations, whilst Pantzalis et al. (2001) claim that operating across more countries reduces exposure. Nance et al. (1993) argue that firms with high likelihood of financial distress are more likely to hedge. Froot et al. (1993) suggest that firms are more likely to hedge when they have considerable growth opportunities. Nance et al. (1993) maintain that firms can reduce the probability of financial distress by holding liquid assets. If liquidity can be viewed as a substitute for hedging, firms with high levels of short-term liquid assets are likely to be more exposed to currency risk. In this study, we use market capitalization $(M V)$, debt-to-assets ratio $(D A)$, market-to-book ratio $(M T B)$ and quick ratio $(Q R)$ as proxies for firm size, financial distress, growth opportunities and asset liquidity, respectively ${ }^{6}$.

To examine the impact of market return orthogonalization on the determinants of exchange rate exposure, we use $\sqrt{\left|\beta_{i s}\right|}$, and then $\sqrt{\left|\theta_{i s}\right|}$, where $\beta_{i s}$ and $\theta_{i s}$ are estimated from Eqs.(1) and (3), respectively, as the dependent variable in Eq.(7). ${ }^{7}$

\footnotetext{
${ }^{6}$ Our list of firm specific variables is identical to that of Hutson and Stevenson (2010).

${ }^{7}$ Both Domingeuz and Tesar (2006) and Hutson and Stevenson (2010) use the square root of the absolute value of the exposure coefficient as the dependent variable in the cross-sectional regressions. We also use the absolute value of the exposure as the dependent variable and our conclusions remain unchanged. Details are available upon request.
} 
Since firm-specific factors, such as $M V, D A, M T B$ and $Q R$, vary across firms and time, cross-sectional analysis is likely to produce biased estimates. To improve estimation efficiency, we use the following panel data approach

$$
\psi_{i, n}=\varphi_{0}+\sum_{k=1}^{K} \varphi_{k} x_{i k, n}+\kappa_{i, n}
$$

where $\psi_{i, n}$ is the exposure of a firm $i$ in a year $n, n=1,2, \ldots, 20 ; x_{i k, n}$ is the $k$ th explanatory variable associated with firm $i$ in year $n$; and $\kappa_{i, n}$ is the disturbance term which can be heteroskedastic. Again for comparison purposes, Eq.(8) is estimated with $\sqrt{\left|\beta_{i s, n}\right|}$ and then with $\sqrt{\left|\rho_{i s, n}\right|}$ as the dependent variable.

\section{Data and descriptive statistics}

We study the foreign exchange exposure of non-financial UK firms listed in the London Stock Exchange over the period from January 1991 to December 2010. Excluding financial firms allows us to focus our analysis on the end-users rather than the producers of financial services and enables us to compare our results to previous studies. To be included in the sample, a stock requires a complete set of weekly price observations to be available from DataStream ${ }^{8}$. Our final sample consists of 269 companies.

Weekly price data of the FTSE All Share index, weekly nominal exchange rate series of the Bank of England effective trade-weighted currency index (TWC), the Euros/£, the US\$/£, the JP¥/£ and the year-end values of a stock’s market capitalization $(M V)$, debt-to-assets ratio $(D A)$, market-to-book ratio $(M T B)$ and quick ratio $(Q R)$ are obtained from DataStream. The descriptive statistics of these variables are reported in Table 1. Figure 1 also presents the movements of the different currency measures across the sample period. It shows that, during the period 1999-2004, the pound depreciated against the dollar and the yen and appreciated against the euro keeping the TWC relatively stable. Thus, the TWC masks the divergence in the currencies and therefore the foreign exchange exposure for companies during this period. Figure 1 also shows a significant depreciation of the pound against all the four currency measures resulting in about 25\% drop in the TWC from mid-2007. This finding is consistent with Fraser and Pantzaliz (2004), who suggest that the exposure of US multinationals to

\footnotetext{
${ }^{8}$ This restriction is required to allow the time varying parameters in Eqs.(4) through (6) to be comparable across the different firms.
} 
foreign exchange fluctuations depends on the currency measures used in the exposure regression.

Panel A of Table 1 presents summary statistics for weekly returns on FTSE All shares and weekly exchange rate changes for the period 1991-2010. The mean values of the exchange rate changes are negative, ranging from a low $-0.07 \%$ for the JP¥/£ to $-0.2 \%$ for the Euro/£, while the average returns on the FTSE All share index is positive $(0.10 \%)$. The standard deviation figures indicate that the exchange rate changes are less volatile than changes in the stock market index. Panel B of Table 1 reports summary statistics of $M V, D A$, $M T B$ and $Q R$ across different time periods. While $Q R$ is relatively stable over time, the Kruskal Wallis test indicates that the medians of $M V, D A$ and $M T B$ vary significantly across sub-periods. If these variables are the determinants of foreign exchange exposure, their variations would suggest that exchange rate risk may not be constant over time. Panel $\mathrm{C}$ presents the correlation matrix of $M V, D A, M T B$ and $Q R$. The absolute values of the correlation coefficients range from a high of 0.241 (between $D A$ and $Q R$ ) and a low of 0.034 (between $D A$ and $M T B$ ).

\section{[Insert Table 1 and Figure 1 about here]}

\section{Empirical results}

\subsection{Unconditional exposure}

Table 2 presents the results of the exchange rate coefficients in Eqs. (1), (2) and (3). Panel A of Table 2 indicates that, based on the statistical significance of the currency coefficients of Jorion's model (Eq.(1)), 14.9\%, 12.3\%, 11.2\% and 16\% of the sample firms are exposed, directly or indirectly, to the fluctuations in the TWC, the Euros, the US\$ and the JP¥, respectively. It also shows that $30.5 \%$ of the firms are significantly exposed to at least one of the three currencies over the period 1991-2010. Although these findings are not as strong as the theory would suggest, they are comparable to other UK studies. El-Masry et al. (2007), for example, show that $15 \%$ of the UK firms are exposed to the changes in the TWC over the period 1981-2001. Similarly, Hutson and Stevenson (2010) find that only $8 \%$ of the UK firms experience significant exposure to the movements in the TWC during the period 1984-2003.

\section{[Insert Table 2 about here]}


Priestley and Ødegaard (2007) attribute the weak empirical association between industry index returns and exchange rate changes to the fact that Jorion's model captures the industry's exposure over and above that of the market portfolio. They argue that a total exposure can be obtained by orthogonalizing market returns. Panel B of Table 2 suggests that the market portfolio is significantly (negatively) exposed the movements in the TWC and the US\$, but not significantly exposed to the Euro and the JP¥. While the exposure to the fluctuations in the TWC decreases slightly (from $14.9 \%$ to $13.75 \%$ ), the percentage of firms with significant exposure to the movements in individual currencies increases with the use of orthogonalized market returns in the exposure regressions. Specifically, Panel C of Table 2 indicates that, based on the statistical significance of the exchange rate coefficients in Eq.(3), $13.38 \%, 13.01 \%$ and $39.03 \%$ of the sample firms are significantly affected by the movements in the US\$, the Euro and the JP¥, respectively. It also shows that $52.8 \%$ of the stocks are exposed to at least one of the three major currencies during the study period.

\subsection{Conditional exposure}

The above analysis is based on the assumption that the exchange rate exposures of the market portfolio and individual firms are constant over time. To relax this assumption, we use Eqs.(4), (5) and (6) to estimate the time varying currency exposures ${ }^{9}$. Table 3 reports the results of the yearly exchange rate coefficients, $\beta_{i s, n}$, in Eq.(4) ${ }^{10}$. Panel A of Table 3 shows that the relationship between stock returns and exchange rate movements is not stable over time. The mean values of exposure to the TWC vary drastically across years, from a high value of 0.50 in 2007 to a low value of -0.66 in 1991. Out of the 20 average yearly TWC coefficients, 13 are statistically significant (7 positive and 6 negative). The percentage of firms with significant exposure to the movements in the TWC also varies substantially from a high of $35.7 \%$ in 1998 to a low of $7.8 \%$ in 2004. The results in Panel A also suggest that the exposure patterns vary across currencies. For example, in 1994, the UK firms exhibit, on average, a negative exposure to the US\$ and a positive exposure to the Euro and the JP¥. The percentage of firms with a significant exposure to at least one currency in a given year ranges from a low of $17.5 \%$ in 1994 to a high of $61.0 \%$ in 1998.

\footnotetext{
${ }^{9}$ Note that the standard OLS estimation of Eqs.(4), (5) and (6) leads to similar conclusions. Detailed results are available upon request.

${ }^{10}$ We also find significant time varying market betas. Since the main purpose of this paper is to examine the foreign exchange exposure, we choose not to report the time varying market betas in order to save space.
} 
The Wald test results in Panel B of Table 3 reject the hypothesis that the coefficients on TWC in Eq.(4) are jointly equal to zero for all 20 years in the sample for $75.84 \%$ of the sample firms. Similar results are also reported when individual currencies, rather than a currency index, are used as exposure measures. Specifically, the Wald test indicates that $73.98 \%, 72.86 \%$ and $72.49 \%$ are exposed to the fluctuations in the US\$, the Euro and the JP¥ during the study period, respectively. It also shows that $78.07 \%$ of the sample firms are exposed to at least one of the three currencies during the study period. Based on the statistical significance of the individual currency coefficients in the GARCH-TVC model, $98.88 \%$ of the sample firms are significantly exposed, directly or indirectly, to at least one of the three currencies in at least one of the 20 years in the sample.

\section{[Insert Table 3 about here]}

Table 4 reports the results of the time varying exchange rate coefficients, $a_{s, n}$, in Eq.(5). It shows that the foreign exchange exposure of the market portfolio varies both over time and across exchange rate measures. Our result indicates that yearly market portfolio exposure to the TWC, the US\$, the Euro and the JP¥ is statistically significant in 4, 9, 6 and 5 out of the 20 years in the sample, respectively. We also show that the market portfolio is exposed to at least one of the three individual currencies in 10 out the 20 years in the sample. These results imply that the market portfolio is exposed in dynamic fashion to the currency movements.

\section{[Insert Table 4 and 5 here]}

Table 5 summarizes the results of the time varying currency coefficients, $\rho_{i s, n}$, in Eq.(6). Panel A reports the yearly changes in the exposure parameters. It shows that orthogonalizing market returns increase the exposure of the UK firms to the exchange rate changes. Panel B shows the results of the Wald test. It suggests that $85.13 \%, 86.99 \%, 78.07 \%$ and $89.96 \%$ of the sample firms are exposed to the movements in the TWC, the US\$, the Euro and the JP¥, respectively. It also indicates that $96.65 \%$ of the sample firms are exposed to at least one of the three currencies over the study period. The results in Table 5 also indicate a preponderance of mean positive exposure coefficients for all currency measures during the period 2007-2009. As shown in Figure 1, this period coincides with the marked depreciation 
of the pound against all the four currency measures making UK exports more competitive. A mean positive exposure during this period will suggest that a depreciation of the pound hurts UK firms. But, that cannot be the case as UK imports during this period are known to have declined more than its exports. ${ }^{11}$ The period also coincides with the general decline of stock prices in the UK and across the world. The exogenous decline of the stock market in association with a depreciation of the pound against the four currency measures can result in a spurious positive foreign exchange exposure. ${ }^{12}$ The observed positive exposures in the 2007 - 2009 period could therefore, and most likely, be spurious rather than causal, arising from the concurrent decline of the stock market and the depreciation of the pound.

Figure 2 illustrates the distribution of the significant exposure coefficient across firms. Panel A of Figure 2 shows results relating to firm exposure to the TWC. It also shows that when actual (orthogonalized) market returns are used in the exposure regressions, the highest number of significant exposures for any firm is 11 (12) out of 20 but the most common number is 3 (5). Panels B to D of Figure 2 show similar results for the exposure to the three major currencies.

Thus, our approach shows a much stronger association between stock returns and exchange rate changes than previous studies in the literature (see e.g. Fraser and Pantzaliz, 2004; Muller and Verschoor; 2006, El-Masry et al., 2007; Hutson and Stevenson, 2010). These findings are consistent with the predictions of the analytical research, which suggest that all firms should be exposed, either directly or indirectly, to exchange rate fluctuations.

\section{[Insert Figure 2 about here]}

\subsection{The determinants of foreign exposure}

The results discussed above show that there are both temporal and cross-sectional differences in the way changes in exchange rates affect firm returns. In this section we explore the role of firm-specific characteristics in determining exchange rate exposure. Tables 6 and 7 present a summary of the results obtained in estimating Eqs.(7) and (8) for each of the four currency measures. For the cross-sectional analysis presented in Table 6, we find weak evidence that firm characteristics influence a firm's exposure to foreign exchange risk. Using the orthogonalized unconditional foreign exchange exposure coefficients as the dependent

\footnotetext{
${ }^{11}$ See Chart 1 of Kamath and Paul (2011), UK net trade increased over this period.

${ }^{12}$ The general stock market decline in the $2007-2009$ period is considered an exogenous shock as this affected all firms and appears unrelated to underlying economic fundamentals.
} 
variable, we find that most of the explanatory variables are not statistically significant (at 5\% level). We also find that the statistical significance of the explanatory variables depends largely on the currency measure used. Specifically, we do not find any significant association between firm characteristics and foreign exchange exposure when using exposure to the TWC or the Euro as the dependent variable. However, we find that firms with high MTB have a higher exposure to the US\$ and large firms also tend to have a higher exposure to the JP¥. This result is consistent with the view that currency exposure as measured by the trade weighted currency index may fail to capture the true extent of a firm's foreign exchange rate exposure (Aggarwal and Harper, 2010; Rees and Unni, 2005).

The results for the unorthogonalized (Panel A of Table 6) and the orthogonalized (Panel B of Table 6) versions are largely similar in terms of direction, magnitude and statistical significance of the determinants except where the dependent variable is exposure to the JP¥. With exposure to the JP¥, we observe a change in statistical significance and/or a change in the sign of the determinants. Overall, the cross-sectional results suggest that firm characteristics have very little or no impact on its exposure to foreign exchange risk. However, since cross-sectional analysis ignores the temporal dimension of both dependent and explanatory variables, this conclusion may be misleading.

We use panel regressions to allow foreign exchange exposure and its potential determinants to vary over time and across firms. Table 7 presents estimates of the panel data analysis, where we estimate a generalised least squares (GLS) regression of the unorthogonalized foreign exchange exposure coefficients on firm characteristics as indicated in Eq.(8). As in Table 6, the explanatory variables include a constant, $M V, D A, M T B$ and $Q R$. The regressions are estimated for each of the four currency measures, with fixed effects, time effects and both fixed and time effects. ${ }^{13}$ The results from the unorthogonalized and orthogonalized foreign exchange exposure coefficients are presented in Panels A and B of Table 7, respectively. We find that, regardless of the estimation process, $D A$ is a significant determinant of the exposure to movements in JP¥. Thus, high leveraged firms tend to have a higher exposure to the JP¥. However, with exposure to the TWC, the US\$ and the Euro the significance of the coefficient on $D A$ depends on the estimation technique. Specifically, the

\footnotetext{
${ }^{13} \mathrm{GLS}$ with fixed effects controls for unobserved variables that vary across firms but not over time; GLS with time effects controls for unobserved variables that are fixed across firms but vary over time; and GLS with both fixed and time effects introduces time dummies to control for both fixed effects and time effects. The data set is an unbalanced panel due to missing data for some firms. It is therefore not feasible to do a random effects model.
} 
coefficient is significant in both the fixed firm and time effect regressions (when considered separately) but the impact diminishes in the combined fixed and time effects.

Panel A shows that MTB is negatively associated to the unorthogonalized exposure to the TWC. This result is robust regardless of how panel regressions are estimated. Panel B reports a negative association between $M T B$ and the orthogonalized exposure to the TWC in both the time effects and the combined time and fixed effects regressions. This result suggests that firms with considerable growth opportunities tend to have a lower exposure to changes in the TWC. The lower exposure of growth firms is thus consistent with the view that such firms are more likely to hedge (Froot et al. 1993). The relationship between MTB and exposure to individual currencies is less clear. The coefficient on MTB is only significant (negative) when the exposure to the US\$ is estimated using actual, rather than orthogonalized, market returns and panel regressions are estimated with the fixed effects or the combined fixed and time effects. The coefficient on $M T B$ is positive and significant in the Euro exposure regressions. However, its significance disappears when market returns are orthogonalized and the combined fixed and time effects are used. Growth opportunities do not seem to affect the exposure to JP¥ in any of the regressions.

The coefficient associated with the $Q R$ also shows some mixed results. The significance of the coefficients depends on the currency measure and/or the estimation process in the panel data regressions. Table 7 suggests that liquidity (measured by QR) does not affect firm’s exposure to the TWC, US\$ or JP¥. This is particularly the case when exposure is estimated from the orthogonalized market return regressions. However, Panel B shows that, regardless of the panel estimation method, QR is negatively and significantly associated with the exposure the Euro.

The most consistent result relates to the role of size on exchange rate exposure. Regardless of the currency measure and the estimation procedure, the coefficient on $M V$ is significantly less than zero. Thus, larger firms tend to have a lower exposure to foreign exchange risk. The negative relationship between size and the measures of exposure is consistent with the "ability to hedge" argument. Large firms are more likely to use both operational and financial hedging techniques to reduce their exposures (Pantzalis et al., 2001).

\section{Conclusion}

Using a sample of 269 UK firms, this study shows that both exchange rate exposure and its determinants are sensitive to the estimation methods. Consistent with the existing 
studies, the standard Jorion's model provides weak evidence of foreign exchange exposure. We attribute the lack of a strong empirical association between stock returns and currency movements to bad-model problems.

One important weakness of Jorion's model is the assumption that foreign exchange exposure is constant over time. Since firm's circumstances, including the extent of international operations and risk management activities, change over time, its currency risk exposure is also expected to vary over time. Thus, using a single coefficient to measure a firm's exposure to foreign exchange changes over a relatively long period of time may be misleading. For example, if a firm experiences a significantly positive exposure in year 1 and a significantly negative exposure with the same magnitude in year 2, the exposure coefficient is unlikely to be significant if Jorion's model is estimated over the two-year period. We use a GARCH-based two-factor asset pricing model with time varying parameters (GARCH-TVC) to allow currency risk exposure to vary over time. Our findings indicate that the majority of our firms are exposed to foreign exchange risk. Specifically, we find that over $75.84 \%$ of the sample firms experience significant exposure to the TWC in one or more years during the study period. It also shows that $78.07 \%$ of the firms exhibit significant exposure to at least one of the three major currencies (US\$, Euro or JP¥) at some point in time, during the study period.

Priestley and $\varnothing$ degaard (2007) argue that the exposure coefficient obtained from regressing stock returns against market returns and exchange rate changes captures only the firm's exposure over and above that of the market portfolio. They claim that a firm's total exposure should be estimated using orthogonalized, rather than actual, market returns in the exposure regression. This study improves on Priestley and $\varnothing$ degaard's (2007) work by allowing for the time variations in the parameters and the residuals of the orthogonalized regressions. The orthogonalized GARCH-TVC indicates a strong association between exchange rate movements and stock returns. The Wald test on the currency coefficients of the orthogonalized GARCH-TVC model suggest that $85.13 \%(96.65 \%)$ are exposed, directly or indirectly, to the movements in the TWC (US\$, Euro or JP¥) during the sample period.

Our results also indicate that the determinants of foreign exchange exposure are model-dependent. While the cross-sectional analysis suggests specific-firm factors, such size, leverage, growth opportunities and liquidity, have very little or no impact on a firm's exposure to foreign exchange risk, pooling the data across firms and time increases the explanatory power of some of these factors. 


\section{Reference}

Agarwal, S., and Ramaswami, S.N., (1992), Choice of foreign market entry mode: Impact of ownership, location and international factors, Journal of International Business Studies 23(1), 1-27.

Aggarwal, R., and Harper, J.T., (2010), Foreign exchange exposure of "domestic" corporations, Journal of International Money and Finance 29, 1619-1636.

Allayannis, G., and Ofek, E., (2001), Exchange rate exposure, hedging, and the use of foreign currency derivatives, Journal of International Money and Finance, 20 (2), 273-296.

Allayannis,G., and Weston, J.P., (2001), The use of foreign currency derivatives and firm market value, Review of Financial Studies 14, 243-276.

Amihud, Y., (1994), Exchange rates and the valuation of equity shares. In: Amihud, Y., Levich, R.M. (Eds), Exchange Rate and Corporate Performance. Irwin, New York, 4959.

Baltagi, B.H., Econometric analysis of panel data, third edition, (2005), John Wiley \& Sons Ltd.

Bartov, E., and Bodnar, G.M., (1994), Firm valuation, earnings expectations, and the exchange rate effect, Journal of Finance 49, 1755-1785.

Bartram, S.M., Brown, G.M., and Minton, B.A., (2010), Resolving the exposure puzzle: The many facets of exchange rate exposure, Journal of Financial Economics 95, 148 - 173.

Berkman, H., Bradbury, M.E., and Magan, S., (1997), An international comparison of derivatives use, Financial Management 26(4), 69-71.

Bodnar, G.M., and Gentry, W.M., (1993), Exchange rate exposure and industry characteristics: Evidence from Canada, Japan and the US, Journal of International Money and Finance 12, 29-45.

Bodnar, G.M., Dumas, B., and Marston, R.C., (2002), Pass-through and exposure, Journal of Finance 57 (1), 199-231.

Bodnar, G.M., and Wong, F.M.H., (2003), Estimating exchange rate exposure: Issues in model structure, Financial Management 32, 35-67.

Bollerslev, T., Chou, R., and Kroner, K., (1992), ARCH modeling in Finance: A review of the theory and empirical evidence, Journal of Econometrics 52, 5-69.

Booth, L., Rotenbery, W., (1990), Assessing foreign exchange exposure: Theory and application using Canadian firms, Journal of International Financial Management and Accounting 2, 1-22.

Chow, E.H., Lee, W.Y., and Solt, M.E., The exchange rate exposure of asset returns, Journal of Business 70, 105-123.

De Jong, J., Ligterink, J., and Macrae, V., (2006), A firm-specific analysis of the exchangerate exposure of Dutch firms, Journal of International Financial Management and Accounting 17, 1-28.

Dominguez, K.M.E, and Tesar, L.L., (2001), trade and exposure, American Economic Review 91(2), 367-370.

Dominguez, K.M.E, and Tesar, L.L., (2006), Exchange rate exposure, Journal of International Economics 68(1), 188-218.

Dunne, T.M., Hellier, C., Power, D., Mallin, C.A., Ow-Yong, K.H., and Moir, L., (2004), The introduction of derivates reporting in the UK: a content analysis of FRS13 disclosures, Journal of Derivatives Accounting 1(2), 205-219.

El-Masry, A., Abdel-Salam, O., and Alatraby, A., (2007), The exchange rate exposure of UK non-financial companies, Managerial Finance 33 (9), 620-641.

Froot, K.A., Scharfstein, J.S., and Stein, J.C., (1993), Risk management: Coordinating corporate investment and financing policies, Journal of Finance 48 (5), 1629-1658. 
Fraser, S., and Pantzaliz, C., (2004), Foreign exchange exposure of US multinational corporations: a firm specific approach, Journal of Multinational Financial Management 14, 261-281.

Hagelin, N., and Pramborg, B., (2006), Empirical evidence concerning incentives to hedge transaction and translation exposure, Journal of Multinational Financial Management $16(2), 142-159$.

Heckman, C.R., (1985), A financial model of foreign exchange exposure, Journal of International Business Studies 41 (2), 83-99.

Hutson, E., and Stevenson, S., (2010), Openness, hedging incentives and foreign exchange exposure: A firm-level multi-country study, Journal of International Business Studies 41, 105-122.

Jorion, P., (1990), The exchange rate exposure of US multinationals, Journal of Business 63 (3), 331-345.

Kamath, K and Paul, V., (2011), Understanding recent developments in UK external trade, Bank of England Quarterly Bulletin, 51 (4), 294-304

Levi, M.D., (1994), Exchange rate and the evaluation of firms. In Amihud, Y., Levich, R.M. (Eds.), Exchange Rate and Corporate Performance, Irwin, New York, pp. 37-48.

Marston, R.C., (2001), The effect of industry structure on economic exposure, Journal of International Money and Finance 20, 149-164.

Muller, A., and Verschoor, W.F.C., (2006), Asymmetric foreign exchange exposure: Evidence from U.S. multinational firms, Journal of Empirical Finance 13, 495-518.

Nance, D.R., Smith, C., and Smithson, C., (1993), On the determinants of corporate hedging, Journal of Finance 48(1), 267-284.

Nguyen, H., and Faff, R., (2003), Can the use of foreign currency derivatives explain the variations in foreign exchange exposure? Evidence from Austrian companies, Journal of Multinational Financial Management 13(3), 193-215.

Nydahl, S., 1999, Exchange rate exposure, foreign involvement and currency hedging of firms: Some Swedish evidence, European Financial Management 5(2), 241-257.

Pantzalis, C., Simkins, B.J. and Laux, P.S., (2001),Operational hedges and the foreign exchange of US multinational corporations, Journal of International Business Studies 32 (4), 793-812.

Patro, D.K., Wald, J.K., and Wu, Y., (2002), Explaining exchange rate risk in world stock markets: A panel approach, Journal of Banking and Finance 26, 1951-1972.

Priestley, R., and Ødegaard, B.A., (2007), Linear and nonlinear exchange rate exposure, Journal of International Money and Finance 26, 1016-1037.

Rees, W. and Unni, S (2005), Exchange rate exposure among European firms: evidence from France, Germany and the UK, Accounting and Finance 45, 479-497

Shapiro, A.C., (1975), Exchange rate changes, inflation and value of multinational corporations, Journal of Finance (May), 485-502.

Smith, C.W., and Stulz, R.M., (1985), The determinants of firm's hedging policies, Journal of Financial and Quantitative Analysis 20(4), 391-405.

Tai, C-S., (2008), Asymmetric currency exposure and currency risk pricing, International Review of Financial Analysis 17, 647-663.

Williamson, R., (2001), Exchange rate exposure and competition: Evidence from the automotive industry, Journal of Financial Economics 59, 441-475. 
Table 1: Summary statistics for currency measure, market index and firm characteristics

Panel A: summary statistics for weekly returns on FTSE All share index and weekly exchange rate changes

\begin{tabular}{cccccc}
\hline & Mean & Median & Max & Min & SD \\
\hline MKT & 0.10 & 0.23 & 12.11 & -22.55 & 2.29 \\
TWC & -0.02 & 0.05 & 6.69 & -6.72 & 0.99 \\
US\$/£ & -0.02 & 0.05 & 4.97 & -10.16 & 1.38 \\
Euro/£ & -0.02 & -0.01 & 7.60 & -5.44 & 1.10 \\
JP¥/£ & -0.07 & 0.05 & 7.51 & -17.13 & 1.92 \\
\hline
\end{tabular}

Panel B: Summary statistics for firm specific factors across different time periods

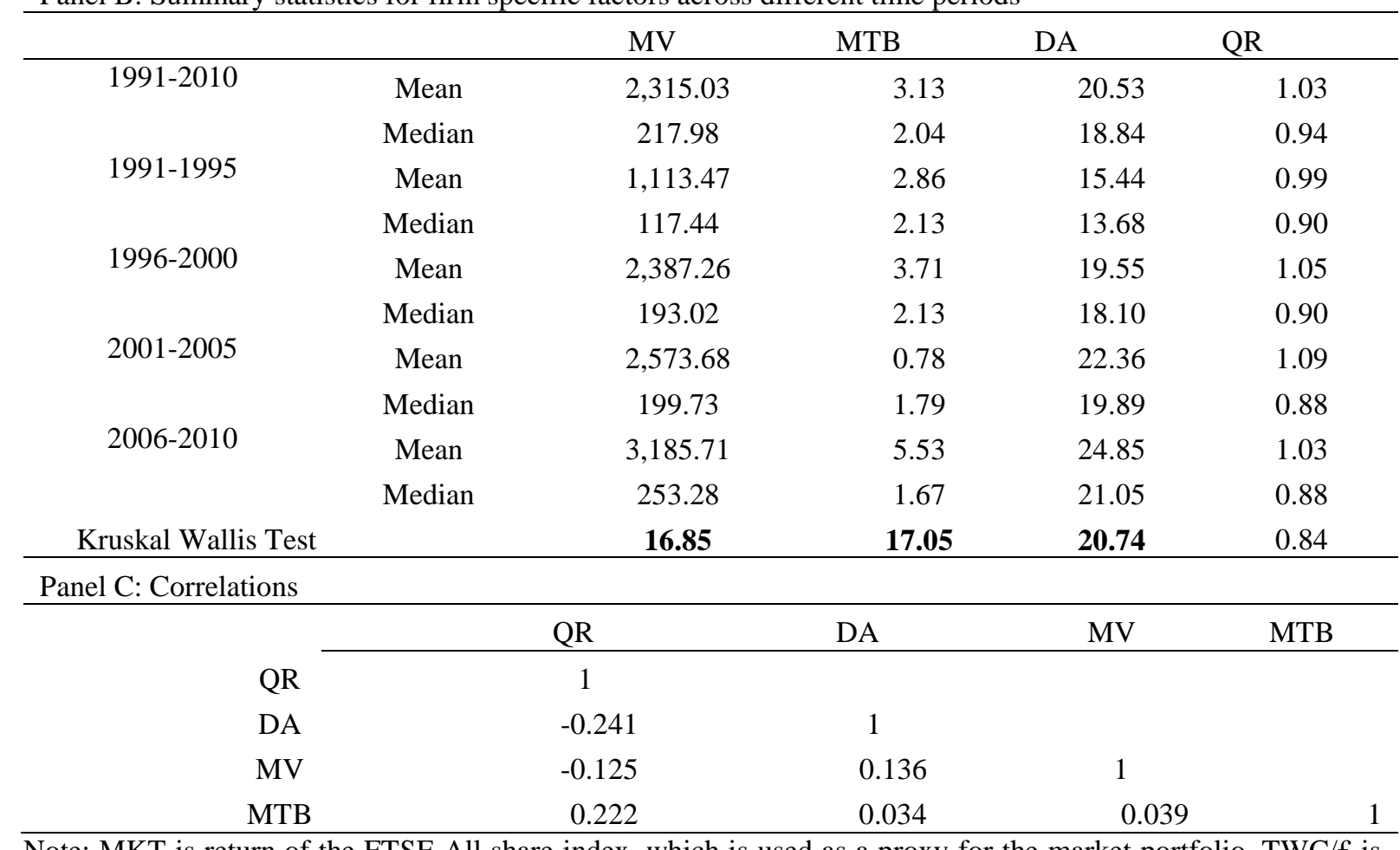

Note: MKT is return of the FTSE All share index, which is used as a proxy for the market portfolio, TWC/£ is the change in the Bank of England's trade-weighted exchange rate index, US\$/£ is the change in US dollar to the UK pound exchange rate, Euro/£ is the change in Euro to the UK pound exchange rate and JP¥/£ is the change in Japanese Yen to the UK pound exchange rate, MV is the market capitalization measured in millions of pounds, MTB is the market-to-book ratio, DA is the debt to asset ratio and QR is the quick ratio. The figures in bold indicate significance at $5 \%$ level. 
Table 2: The unconditional exposure of the UK firms and the FTSE All share index

\begin{tabular}{ccccccc}
\hline & $\begin{array}{c}\text { Panel A: The exchange rate } \\
\text { coefficient of the standard } \\
\text { Jorion's model (Eq.(1)) }\end{array}$ & \multicolumn{2}{c}{$\begin{array}{c}\text { Panel B: The FTSE All } \\
\text { share index exposure to } \\
\text { currency risk (Eq.(2)) }\end{array}$} & \multicolumn{2}{c}{$\begin{array}{c}\text { Panel B: The exchange rate } \\
\text { coefficient of orthogonalized } \\
\text { Jorion's model (Eq.(3)) }\end{array}$} \\
\hline Mean & \%sign & Coefficient & t-statistic & Mean & \%sign \\
\hline TWC & $\mathbf{0 . 0 6 3}$ & $14.93 \%$ & $\mathbf{- 0 . 1 7 3}$ & -3.375 & $\mathbf{0 . 0 4 1}$ & $13.75 \%$ \\
Euro/£ $\$ £$ & $\mathbf{0 . 0 4 0}$ & $12.32 \%$ & $\mathbf{- 0 . 1 8 1}$ & -5.455 & 0.003 & $13.38 \%$ \\
JP¥/£ & $\mathbf{0 . 0 3 7}$ & $11.21 \%$ & -0.007 & -0.134 & $\mathbf{0 . 0 6 5}$ & $13.01 \%$ \\
OFT & $\mathbf{0 . 0 2 5}$ & $16.00 \%$ & 0.017 & 0.684 & $\mathbf{0 . 1 1 7}$ & $39.03 \%$ \\
\hline
\end{tabular}

Note: TWC is the change in the Bank of England's trade-weighted exchange rate index, US\$/£ is the change in US dollar to the UK pound exchange rate, Euro/£ is the change in Euro to the UK pound exchange rate and JP¥/£ is the change in Japanese Yen to the UK pound exchange rate, \%sign is the percentage of firms with significant exposure (at 5\% level) to a given currency measure, OFT is percentage of firms with significant exposure to at least one of the three major currencies (US\$, Euro or JP¥) during the sample period. The figures in bold indicate significance at $5 \%$ level. 
Table 3: The conditional exposure of the UK firms (GARCH-TVC model, or Eq.(4))

\begin{tabular}{|c|c|c|c|c|c|c|c|c|c|}
\hline \multicolumn{10}{|c|}{ Panel A: Yearly currency exposure } \\
\hline & \multicolumn{2}{|c|}{ TWC } & \multicolumn{2}{|c|}{$\mathrm{US} \$ / £$} & \multicolumn{2}{|c|}{ Euro/£ } & \multicolumn{2}{|c|}{ JP¥/£ } & \multirow{2}{*}{$\begin{array}{l}\text { OFT } \\
\% \text { Sig }\end{array}$} \\
\hline & Mean & $\%$ sig & Mean & $\%$ Sig & Mean & $\%$ Sig & Mean & $\% \mathrm{Sig}$ & \\
\hline 1991 & -0.660 & $16.4 \%$ & -0.271 & $20.8 \%$ & -0.379 & $15.2 \%$ & -0.077 & $12.6 \%$ & $38.3 \%$ \\
\hline 1992 & 0.150 & $20.8 \%$ & 0.029 & $21.2 \%$ & 0.001 & $19.3 \%$ & -0.024 & $21.9 \%$ & $33.5 \%$ \\
\hline 1993 & 0.288 & $19.7 \%$ & 0.128 & $13.0 \%$ & 0.205 & $18.6 \%$ & 0.071 & $13.0 \%$ & $31.2 \%$ \\
\hline 1994 & -0.115 & $8.6 \%$ & 0.089 & $5.2 \%$ & -0.143 & $7.4 \%$ & -0.083 & $10.0 \%$ & $17.5 \%$ \\
\hline 1995 & 0.102 & $10.0 \%$ & -0.064 & $10.8 \%$ & 0.050 & $8.9 \%$ & 0.068 & $11.2 \%$ & $20.8 \%$ \\
\hline 1996 & 0.124 & $11.5 \%$ & -0.017 & $13.0 \%$ & 0.112 & $14.5 \%$ & 0.003 & $11.2 \%$ & $23.0 \%$ \\
\hline 1997 & -0.142 & $20.1 \%$ & -0.226 & $20.1 \%$ & -0.172 & $21.2 \%$ & 0.019 & $19.0 \%$ & $38.3 \%$ \\
\hline 1998 & -0.226 & $35.7 \%$ & -0.242 & $31.2 \%$ & -0.203 & $32.0 \%$ & 0.101 & $27.5 \%$ & $61.0 \%$ \\
\hline 1999 & -0.090 & $14.5 \%$ & -0.136 & $17.1 \%$ & -0.030 & $18.6 \%$ & -0.033 & $17.5 \%$ & $37.9 \%$ \\
\hline 2000 & -0.210 & $23.4 \%$ & -0.212 & $20.1 \%$ & -0.112 & $27.1 \%$ & -0.078 & $23.0 \%$ & $49.4 \%$ \\
\hline 2001 & -0.048 & $23.0 \%$ & 0.019 & $19.3 \%$ & -0.114 & $20.1 \%$ & 0.036 & $21.2 \%$ & $45.4 \%$ \\
\hline 2002 & -0.256 & $16.7 \%$ & 0.153 & $23.8 \%$ & -0.169 & $16.4 \%$ & -0.010 & $23.0 \%$ & $45.0 \%$ \\
\hline 2003 & -0.010 & $16.4 \%$ & 0.053 & $13.0 \%$ & 0.020 & $15.2 \%$ & -0.280 & $14.5 \%$ & $29.0 \%$ \\
\hline 2004 & 0.313 & $16.4 \%$ & 0.116 & $17.8 \%$ & 0.239 & $13.4 \%$ & 0.028 & $15.6 \%$ & $31.6 \%$ \\
\hline 2005 & 0.226 & $7.8 \%$ & 0.190 & $12.3 \%$ & 0.091 & $9.3 \%$ & 0.114 & $8.9 \%$ & $21.9 \%$ \\
\hline 2006 & 0.023 & $12.6 \%$ & 0.041 & $11.2 \%$ & 0.049 & $14.5 \%$ & 0.014 & $12.6 \%$ & $26.8 \%$ \\
\hline 2007 & 0.500 & $22.3 \%$ & 0.300 & $21.2 \%$ & 0.514 & $19.7 \%$ & 0.265 & $18.6 \%$ & $37.5 \%$ \\
\hline 2008 & -0.144 & $29.0 \%$ & -0.033 & $33.8 \%$ & -0.109 & $26.0 \%$ & -0.085 & $26.4 \%$ & $53.9 \%$ \\
\hline 2009 & 0.308 & $24.2 \%$ & 0.212 & $18.6 \%$ & 0.232 & $23.8 \%$ & 0.115 & $21.2 \%$ & $37.2 \%$ \\
\hline 2010 & 0.133 & $11.9 \%$ & 0.154 & $14.9 \%$ & 0.056 & $12.3 \%$ & 0.110 & $14.5 \%$ & $27.5 \%$ \\
\hline \multicolumn{10}{|c|}{ Panel B: Overall exposure } \\
\hline & \multicolumn{2}{|c|}{ TWC } & \multicolumn{2}{|c|}{$\mathrm{US} \$ / £$} & \multicolumn{2}{|c|}{ Euro/£ } & \multicolumn{2}{|c|}{ JP¥/£ } & OFT \\
\hline$\%$ OSYE & \multicolumn{2}{|c|}{$97.03 \%$} & \multicolumn{2}{|c|}{$94.05 \%$} & \multicolumn{2}{|c|}{$97.03 \%$} & \multicolumn{2}{|c|}{$96.28 \%$} & $98.88 \%$ \\
\hline$\%$ sign (Wald test) & \multicolumn{2}{|c|}{$75.84 \%$} & \multicolumn{2}{|c|}{$73.98 \%$} & \multicolumn{2}{|c|}{$72.86 \%$} & \multicolumn{2}{|c|}{$72.49 \%$} & $78.07 \%$ \\
\hline
\end{tabular}

Note: TWC is the change in the Bank of England's trade-weighted exchange rate index, US $\$ \mathbb{£}$ is the change in US dollar to the UK pound exchange rate, Euro/£ is the change in Euro to the UK pound exchange rate and JP¥/£ is the change in Japanese Yen to the UK pound exchange rate, \%sign is the percentage of firms with significant exposure (at 5\% level) to a given currency measure, OFT is percentage of firms with significant exposure (at 5\% level) to at least one of the three major currencies (US\$, Euro or JP¥) during a given period, \% OSYE refers to the percentage of stocks with at least one significant (at 5\% level) yearly currency exposure, Wald test tests the hypothesis that the yearly currency exposure coefficients are jointly equal to zero for all 20 years in the sample. The figures in bold indicate significance at 5\% level. 
Table 4: The conditional exposure of the FTSE All share index (Eq.(5))

\begin{tabular}{|c|c|c|c|c|c|c|c|c|c|}
\hline \multicolumn{10}{|c|}{ Panel A: Yearly currency exposure } \\
\hline & \multicolumn{2}{|c|}{ TWC } & \multicolumn{2}{|c|}{ US\$/£ } & \multicolumn{2}{|c|}{ Euro/£ } & \multicolumn{2}{|c|}{ JP¥/£ } & \multirow[t]{2}{*}{ OFTM } \\
\hline & Coef & $\mathrm{t}-\mathrm{Stat}$ & Coef & t-Stat & Coef & $\mathrm{t}-$ Stat & Coef & t-Stat & \\
\hline 1991 & 0.577 & 1.118 & -0.024 & -0.132 & 1.272 & 2.252 & 0.025 & 0.145 & Yes \\
\hline 1992 & -0.487 & -4.467 & -0.409 & -4.575 & -0.130 & -0.938 & -0.486 & -4.292 & Yes \\
\hline 1993 & 0.012 & 0.052 & -0.077 & -0.624 & 0.184 & 1.051 & -0.102 & -1.025 & No \\
\hline 1994 & -0.768 & -1.691 & -0.632 & -2.498 & -0.426 & -1.174 & -0.215 & -1.006 & Yes \\
\hline 1995 & -0.094 & -0.358 & -0.259 & -1.312 & -0.020 & -0.105 & 0.026 & 0.222 & No \\
\hline 1996 & 0.244 & 1.013 & 0.024 & 0.142 & 0.404 & 1.455 & 0.048 & 0.354 & No \\
\hline 1997 & -0.429 & -1.931 & -0.776 & -3.428 & -0.217 & -1.015 & -0.367 & -2.309 & Yes \\
\hline 1998 & -0.590 & -1.710 & -0.624 & -2.207 & -0.021 & -0.074 & -0.068 & -0.522 & Yes \\
\hline 1999 & -0.039 & -0.129 & -0.925 & -3.605 & 0.354 & 2.285 & 0.000 & 0.004 & Yes \\
\hline 2000 & -0.334 & -0.972 & -0.168 & -0.894 & -0.088 & -0.332 & -0.147 & -1.375 & No \\
\hline 2001 & -0.195 & -0.533 & 0.195 & 1.554 & -0.094 & -0.438 & 0.053 & 0.384 & No \\
\hline 2002 & -1.334 & -3.621 & -1.310 & -6.142 & -0.389 & -1.456 & -0.531 & -2.412 & Yes \\
\hline 2003 & -0.191 & -0.390 & -0.404 & -1.329 & 0.031 & 0.075 & -0.232 & -0.824 & No \\
\hline 2004 & -0.160 & -0.539 & -0.133 & -0.749 & -0.022 & -0.094 & -0.075 & -0.452 & No \\
\hline 2005 & -0.344 & -1.065 & -0.252 & -1.402 & -0.142 & -0.550 & 0.024 & 0.109 & No \\
\hline 2006 & -0.382 & -1.077 & 0.035 & 0.238 & -0.597 & -1.336 & -0.143 & -0.529 & No \\
\hline 2007 & 0.590 & 2.757 & 0.549 & 2.758 & 0.555 & 2.813 & 0.610 & 5.373 & Yes \\
\hline 2008 & 1.477 & 7.011 & 1.439 & 14.467 & 0.858 & 3.968 & 0.924 & 20.101 & Yes \\
\hline 2009 & -0.227 & -0.630 & 0.389 & 1.047 & -0.435 & -1.476 & 0.459 & 1.895 & No \\
\hline 2010 & -0.329 & -0.928 & 0.299 & 1.972 & -0.536 & -2.232 & 0.548 & 5.775 & Yes \\
\hline
\end{tabular}

Panel B: Wald Test - at least one significant yearly exposure

\begin{tabular}{ccccc}
\hline & TWC & US\$/£ & Euro/£ & JP¥/£ \\
\cline { 2 - 5 } Wald Test $(\mathrm{F})$ & $\mathbf{5 . 3 5 4}$ & $\mathbf{1 6 . 0 3 8}$ & $\mathbf{2 . 4 4 7}$ & $\mathbf{2 5 . 9 8 8}$ \\
\hline
\end{tabular}

Note: TWC is the change in the Bank of England's trade-weighted exchange rate index, US\$/£ is the change in US dollar to the UK pound exchange rate, Euro/£ is the change in Euro to the UK pound exchange rate and JP¥/£ is the change in Japanese Yen to the UK pound exchange rate, \%sign is the percentage of firms with significant exposure (at 5\% level) to a given currency measure, OFTM informs us whether the market index is significantly exposed (at 5\% level) to at least one of the three major currencies (US\$, Euro or JP¥) in a given year, the Wald test tests the hypothesis that the yearly currency exposure coefficients are jointly equal to zero for all 20 years in the sample. The figures in bold indicate significance at $5 \%$ level. 
Table 5: The orthogonalized conditional exposure of the UK firms (Eq.(6))

\begin{tabular}{|c|c|c|c|c|c|c|c|c|c|}
\hline \multicolumn{10}{|c|}{ Panel A: Yearly currency exposure } \\
\hline & \multicolumn{2}{|c|}{ TWC } & \multicolumn{2}{|c|}{$\mathrm{US} \$ / £$} & \multicolumn{2}{|c|}{ Euro/£ } & \multicolumn{2}{|c|}{ JP¥/£ } & \multirow{2}{*}{$\begin{array}{l}\text { OFT } \\
\% \text { Sig }\end{array}$} \\
\hline & Mean & $\%$ sig & Mean & $\% \mathrm{Sig}$ & Mean & $\% \mathrm{Sig}$ & Mean & $\% \mathrm{Sig}$ & \\
\hline 1991 & -0.282 & $14.1 \%$ & -0.331 & $20.8 \%$ & 0.494 & $20.1 \%$ & -0.074 & $13.0 \%$ & $40.1 \%$ \\
\hline 1992 & -0.158 & $28.3 \%$ & -0.247 & $31.6 \%$ & 0.051 & $19.7 \%$ & -0.367 & $39.4 \%$ & $49.4 \%$ \\
\hline 1993 & 0.280 & $19.3 \%$ & 0.089 & $11.5 \%$ & 0.258 & $18.2 \%$ & 0.036 & $12.3 \%$ & $30.9 \%$ \\
\hline 1994 & -0.349 & $9.3 \%$ & -0.247 & $9.7 \%$ & -0.208 & $7.8 \%$ & -0.167 & $11.2 \%$ & $22.7 \%$ \\
\hline 1995 & 0.043 & $11.9 \%$ & -0.158 & $13.0 \%$ & 0.068 & $9.3 \%$ & 0.069 & $10.8 \%$ & $23.4 \%$ \\
\hline 1996 & 0.299 & $14.9 \%$ & 0.038 & $13.0 \%$ & 0.364 & $17.1 \%$ & 0.073 & $10.4 \%$ & $27.1 \%$ \\
\hline 1997 & -0.346 & $24.5 \%$ & -0.507 & $31.2 \%$ & -0.306 & $24.2 \%$ & -0.141 & $22.7 \%$ & $45.0 \%$ \\
\hline 1998 & -0.533 & $35.7 \%$ & -0.627 & $43.1 \%$ & -0.085 & $30.9 \%$ & 0.062 & $26.4 \%$ & $68.0 \%$ \\
\hline 1999 & -0.201 & $15.6 \%$ & -0.539 & $23.0 \%$ & 0.150 & $17.1 \%$ & -0.069 & $18.6 \%$ & $41.3 \%$ \\
\hline 2000 & -0.236 & $23.0 \%$ & -0.270 & $20.1 \%$ & -0.166 & $28.3 \%$ & -0.085 & $22.3 \%$ & $48.3 \%$ \\
\hline 2001 & -0.075 & $21.9 \%$ & -0.063 & $19.0 \%$ & 0.093 & $19.3 \%$ & 0.261 & $23.8 \%$ & $46.1 \%$ \\
\hline 2002 & -1.057 & $29.0 \%$ & -0.654 & $36.8 \%$ & -0.373 & $17.5 \%$ & -0.389 & $29.0 \%$ & $60.2 \%$ \\
\hline 2003 & -0.095 & $16.4 \%$ & -0.384 & $19.3 \%$ & 0.112 & $13.8 \%$ & -0.415 & $16.4 \%$ & $33.8 \%$ \\
\hline 2004 & 0.209 & $15.6 \%$ & 0.033 & $16.7 \%$ & 0.218 & $13.4 \%$ & -0.005 & $16.7 \%$ & $30.5 \%$ \\
\hline 2005 & -0.075 & $9.7 \%$ & -0.003 & $10.8 \%$ & -0.030 & $9.3 \%$ & 0.103 & $8.2 \%$ & $20.1 \%$ \\
\hline 2006 & -0.256 & $13.0 \%$ & 0.049 & $11.5 \%$ & -0.408 & $14.5 \%$ & -0.121 & $13.4 \%$ & $29.0 \%$ \\
\hline 2007 & 0.596 & $23.4 \%$ & 0.488 & $24.9 \%$ & 0.612 & $22.3 \%$ & 0.605 & $49.4 \%$ & $61.0 \%$ \\
\hline 2008 & 0.606 & $50.2 \%$ & 0.683 & $56.9 \%$ & 0.245 & $34.9 \%$ & 0.497 & $64.7 \%$ & $77.7 \%$ \\
\hline 2009 & 0.360 & $24.5 \%$ & 0.537 & $31.6 \%$ & 0.209 & $23.8 \%$ & 0.388 & $38.7 \%$ & $55.4 \%$ \\
\hline 2010 & -0.023 & $15.2 \%$ & 0.297 & $16.0 \%$ & -0.178 & $14.5 \%$ & 0.444 & $38.7 \%$ & $52.4 \%$ \\
\hline \multicolumn{10}{|c|}{ Panel B: Overall exposure } \\
\hline & \multicolumn{2}{|c|}{ TWC } & \multicolumn{2}{|c|}{$\mathrm{US} \$ / £$} & \multicolumn{2}{|c|}{ Euro/£ } & \multicolumn{2}{|c|}{ JP¥/£ } & OFT \\
\hline$\%$ OSYE (t-test) & \multicolumn{2}{|c|}{$98.88 \%$} & \multicolumn{2}{|c|}{$98.14 \%$} & \multicolumn{2}{|c|}{$96.28 \%$} & \multicolumn{2}{|c|}{$98.88 \%$} & $100.00 \%$ \\
\hline$\%$ sign (Wald test) & \multicolumn{2}{|c|}{$85.13 \%$} & \multicolumn{2}{|c|}{$86.99 \%$} & \multicolumn{2}{|c|}{$78.07 \%$} & \multicolumn{2}{|c|}{$89.96 \%$} & $96.65 \%$ \\
\hline
\end{tabular}

Note: TWC is the change in the Bank of England's trade-weighted exchange rate index, US\$/£ is the change in US dollar to the UK pound exchange rate, Euro/ $£$ is the change in Euro to the UK pound exchange rate and JP¥/£ is the change in Japanese Yen to the UK pound exchange rate, \%sign is the percentage of firms with significant exposure (at 5\% level) to a given currency measure, OFT is percentage of firms with significant exposure (at 5\% level) to at least one of the three major currencies (US\$, Euro or JP¥) during a given period, \% OSYE refers to the percentage of stocks with at least one significant (at 5\% level) yearly currency exposure, Wald test tests the hypothesis that the yearly currency exposure coefficients are jointly equal to zero for all 20 years in the sample. The figures in bold indicate significance at $5 \%$ level. 
Table 6: The cross-sectional regression results on the determinants of the foreign exchange exposure (Eq.(7))

Panel A: the square root of the absolute value of the currency coefficient in Eq.(1) as the dependent variable

\begin{tabular}{ccccc} 
& TWC & US $\$$ \& & Euro/£ & JP¥/£ \\
\cline { 2 - 5 } Constant & $\mathbf{0 . 3 9 4 4}$ & $\mathbf{0 . 2 9 2 6}$ & $\mathbf{0 . 4 0 9 6}$ & $\mathbf{0 . 2 4 1 3}$ \\
DA & -0.0005 & -0.0008 & -0.0011 & 0.0005 \\
MV & -0.0020 & 0.0054 & -0.0064 & -0.0001 \\
MTB & -0.0002 & $\mathbf{0 . 0 0 1 0}$ & 0.0004 & $\mathbf{- 0 . 0 0 0 4}$ \\
QR & -0.0027 & 0.0079 & -0.0108 & 0.0116
\end{tabular}

Adjusted $\mathrm{R}^{2}$

$0.3 \%$

$2.4 \%$

$2.3 \%$

$0.7 \%$

Panel B: the square root of the absolute value of the currency coefficient in Eq.(3) as the dependent variable

\begin{tabular}{ccccc} 
& TWC & US\$ $/ £$ & Euro/£ & JP¥/£ \\
\cline { 2 - 5 } Constant & $\mathbf{0 . 3 9 5 7}$ & $\mathbf{0 . 2 8 2 5}$ & $\mathbf{0 . 3 8 9 6}$ & $\mathbf{0 . 2 2 2 6}$ \\
DA & -0.0005 & -0.0006 & 0.0001 & 0.0008 \\
MV & -0.0018 & 0.0041 & -0.0044 & $\mathbf{0 . 0 2 1 1}$ \\
MTB & -0.0003 & $\mathbf{0 . 0 0 1 0}$ & 0.0006 & -0.0001 \\
QR & -0.0031 & 0.0144 & -0.0102 & 0.0102 \\
Adjusted $\mathrm{R}^{2}$ & $0.3 \%$ & $2.4 \%$ & $0.6 \%$ & $11.3 \%$ \\
\hline
\end{tabular}

Note: TWC is the change in the Bank of England's trade-weighted exchange rate index, US\$/£ is the change in US dollar to the UK pound exchange rate, Euro/£ is the change in Euro to the UK pound exchange rate and JP¥/£ is the change in Japanese Yen to the UK pound exchange rate, MV is the market capitalization measured in millions of pounds, MTB is the market-to-book ratio, DA is the debt to asset ratio and QR is the quick ratio. The figures in bold indicate significance at $5 \%$ level. 
Table 7: The panel regression results on the determinants of the foreign exchange exposure (Eq.(8))

\begin{tabular}{|c|c|c|c|c|c|c|c|c|}
\hline \multirow[b]{4}{*}{ Intercept } & \multicolumn{4}{|c|}{$\begin{array}{l}\text { Panel A: the square root of the absolute value of the } \\
\text { Irrency coefficient in Eq.(4) as the dependent variable }\end{array}$} & \multicolumn{4}{|c|}{$\begin{array}{l}\text { Panel B: the square root of the absolute value of the } \\
\text { currency coefficient in Eq.(6) as the dependent variable }\end{array}$} \\
\hline & GLS & $\begin{array}{l}\text { GLS with } \\
\text { Firm } \\
\text { Dummies } \\
\end{array}$ & $\begin{array}{l}\text { GLS with } \\
\text { Period } \\
\text { Dummies } \\
\end{array}$ & $\begin{array}{l}\text { GLS with } \\
\text { both } \\
\text { Period and } \\
\text { Fixed } \\
\text { Dummies } \\
\end{array}$ & GLS & $\begin{array}{l}\text { GLS with } \\
\text { Firm } \\
\text { Dummies }\end{array}$ & $\begin{array}{l}\text { GLS with } \\
\text { Period } \\
\text { Dummies }\end{array}$ & $\begin{array}{l}\text { GLS with both } \\
\text { Period and } \\
\text { Fixed Dummies }\end{array}$ \\
\hline & \multicolumn{4}{|c|}{ TWC } & \multicolumn{4}{|c|}{ TWC } \\
\hline & 1.2592 & 1.6052 & 1.2623 & 1.6922 & 1.1774 & 1.6535 & 1.1742 & 1.7136 \\
\hline DA & 0.0022 & 0.0031 & 0.0016 & 0.0018 & 0.0022 & 0.0029 & 0.0014 & 0.0012 \\
\hline MV & -0.0909 & -0.1615 & -0.0890 & -0.1729 & -0.0699 & -0.1646 & -0.0659 & -0.1690 \\
\hline МТB & -0.0002 & -0.0003 & -0.0002 & -0.0003 & -0.0001 & -0.0003 & -0.0001 & -0.0003 \\
\hline QR & -0.0181 & -0.0117 & -0.0197 & -0.0141 & -0.0171 & -0.0121 & -0.0187 & -0.0154 \\
\hline Wald F & 55.6541 & 2.9632 & 23.8343 & 4.0787 & 31.2322 & 2.7579 & 19.6653 & 3.8923 \\
\hline \multirow[t]{2}{*}{ Adj- $R^{2}$} & 0.0420 & 0.1434 & 0.0977 & 0.1984 & 0.0240 & 0.1348 & 0.0820 & 0.1910 \\
\hline & \multicolumn{4}{|c|}{$\mathrm{US} \$ / £$} & \multicolumn{4}{|c|}{ US\$/£ } \\
\hline Intercept & 0.8991 & 1.0544 & 0.9322 & 1.3368 & 0.7955 & 1.0348 & 0.8186 & 1.2458 \\
\hline DA & 0.0025 & 0.0033 & 0.0017 & 0.0014 & 0.0032 & 0.0042 & 0.0021 & 0.0018 \\
\hline MV & -0.0717 & -0.1034 & -0.0742 & -0.1492 & -0.0435 & -0.0925 & -0.0430 & -0.1228 \\
\hline MTB & 0.0000 & -0.0001 & 0.0000 & -0.0001 & 0.0000 & -0.0001 & 0.0000 & -0.0001 \\
\hline QR & -0.0079 & -0.0122 & -0.0120 & -0.0163 & -0.0058 & -0.0083 & -0.0090 & -0.0120 \\
\hline Wald F & 59.9578 & 2.8353 & 24.7809 & 4.0512 & 22.9081 & 2.5392 & 22.2037 & 4.1174 \\
\hline \multirow[t]{2}{*}{ Adj- $R^{2}$} & 0.0450 & 0.1380 & 0.1011 & 0.1973 & 0.0177 & 0.1254 & 0.0916 & 0.1999 \\
\hline & \multicolumn{4}{|c|}{ Euro/£ } & \multicolumn{4}{|c|}{ Euro/£ } \\
\hline Intercept & 1.1277 & 1.5544 & 1.1096 & 1.5175 & 1.0611 & 1.5395 & 1.0453 & 1.5329 \\
\hline DA & 0.0014 & 0.0018 & 0.0012 & 0.0014 & 0.0016 & 0.0022 & 0.0013 & 0.0016 \\
\hline MV & -0.0825 & -0.1654 & -0.0786 & -0.1568 & -0.0678 & -0.1613 & -0.0642 & -0.1579 \\
\hline МТВ & 0.0003 & 0.0002 & 0.0003 & 0.0002 & 0.0002 & 0.0001 & 0.0002 & 0.0000 \\
\hline QR & -0.0189 & -0.0200 & -0.0175 & -0.0198 & -0.0197 & $\mathbf{- 0 . 0 2 0 7}$ & -0.0184 & -0.0208 \\
\hline Wald F & 64.0172 & 2.9243 & 27.8842 & 4.2156 & 41.2491 & 2.7048 & 21.8493 & 3.8447 \\
\hline \multirow[t]{2}{*}{ Adj- $R^{2}$} & 0.0480 & 0.1417 & 0.1124 & 0.2036 & 0.0314 & 0.1325 & 0.0903 & 0.1891 \\
\hline & \multicolumn{4}{|c|}{ JP¥/£ } & \multicolumn{4}{|c|}{ JP¥/£ } \\
\hline Intercept & 0.6484 & 0.7435 & 0.6701 & 0.9317 & 0.5868 & 0.6888 & 0.6079 & 0.8600 \\
\hline DA & 0.0021 & 0.0030 & 0.0016 & 0.0018 & 0.0025 & 0.0037 & 0.0017 & 0.0020 \\
\hline MV & -0.0501 & -0.0716 & -0.0519 & -0.1025 & -0.0305 & $-\mathbf{0 . 0 5 4 7}$ & -0.0310 & -0.0803 \\
\hline МТВ & 0.0001 & 0.0000 & 0.0001 & 0.0000 & 0.0000 & 0.0000 & 0.0000 & 0.0000 \\
\hline QR & -0.0121 & -0.0127 & -0.0141 & -0.0147 & -0.0093 & -0.0092 & -0.0113 & -0.0113 \\
\hline Wald F & 57.2160 & 2.6966 & 21.7229 & 3.6479 & 24.8231 & 2.6154 & 19.9131 & 3.9099 \\
\hline Adj- $R^{2}$ & 0.0431 & 0.1322 & 0.0898 & 0.1812 & 0.0192 & 0.1287 & 0.0829 & 0.1917 \\
\hline
\end{tabular}

Note: TWC is the change in the Bank of England's trade-weighted exchange rate index, US\$/£ is the change in US dollar to the UK pound exchange rate, Euro/£ is the change in Euro to the UK pound exchange rate and JP¥/£ is the change in Japanese Yen to the UK pound exchange rate, MV is the market capitalization measured in millions of pounds, MTB is the market-to-book ratio, DA is the debt to asset ratio and QR is the quick ratio. The figures in bold indicate significance at 5\% level. 
Figure 1: Exchange rate dynamics: January 1991 - December 2010

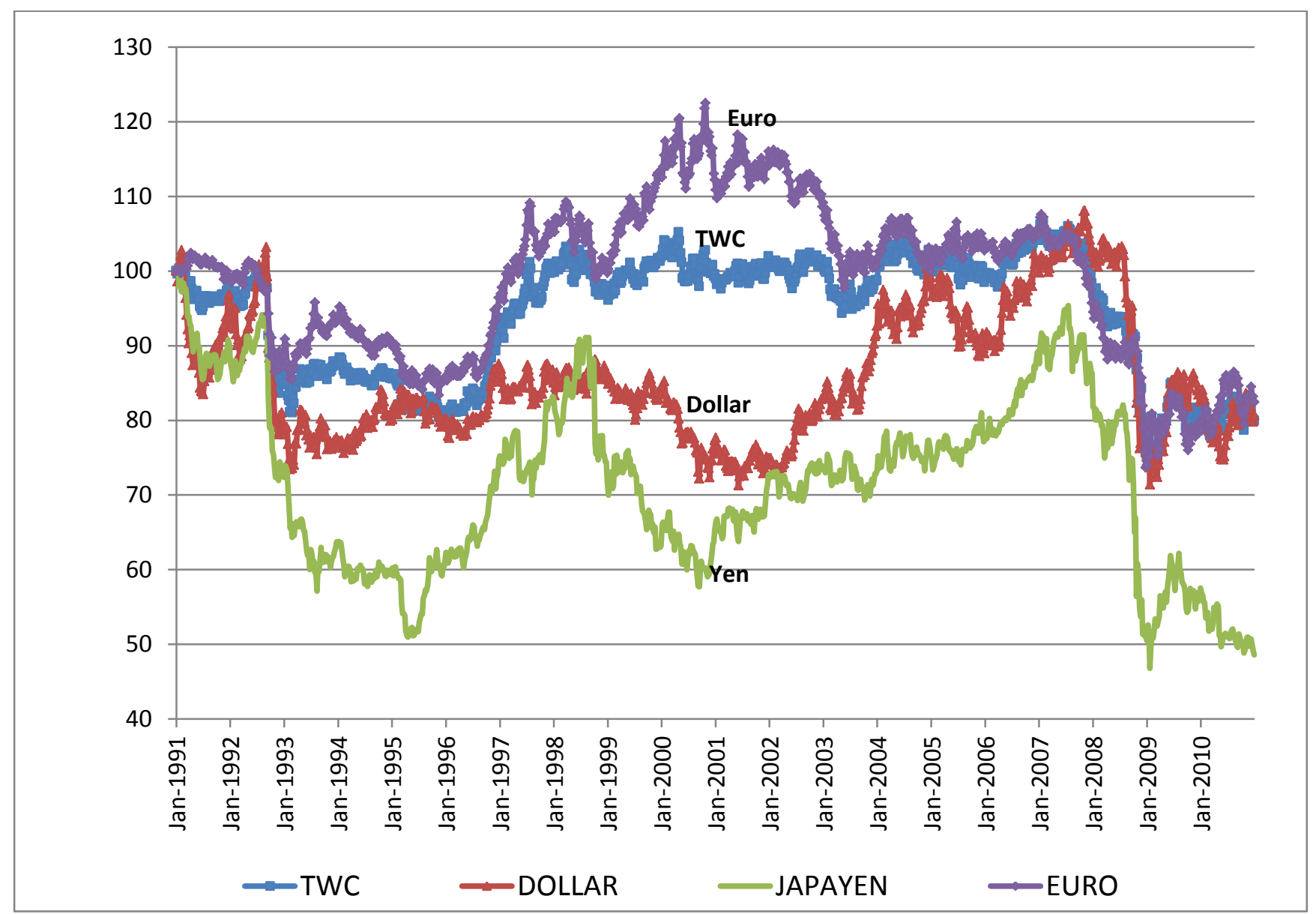

Note: The figure plots the performance of the UK pound against the four currency measures. For comparison purposes, each series is indexed to 100 at the start of January 1991. 


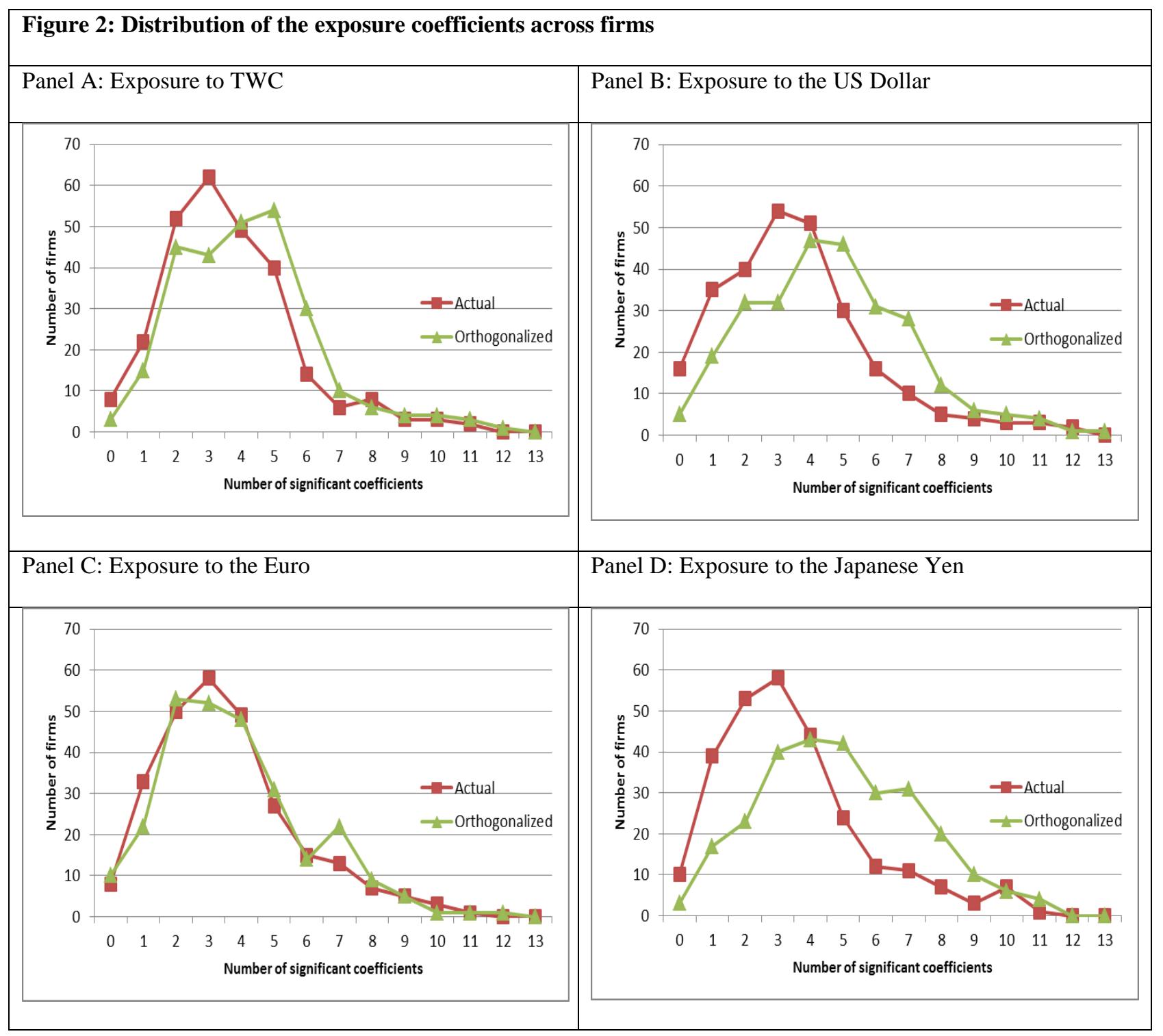

